\title{
Memory, Trust and Fear in Post-Conflict Societies
}

\author{
Djordje Pavićević \\ Faculty of Political Science \\ University of Belgrade
}

\begin{abstract}
The paper deals with the importance of common knowledge based on shared memory for the character of social cooperation. The findings are based on the background of Serbian experience with dealing with the past. The stabilization of a common stock of knowledge is valuable for establishing sustainable patterns of cooperation. The nexus between shared knowledge and different modalities of action is elaborated. Fearful and trustful actions are taken as basic modalities. Both are concerned with uncertainty over time and coping with the freedom of others as independent agents, but they evoke different expectations concerning the prospects of possible cooperation. The common assumptions of mutual expectations are crucial for the choice of cooperative strategy. Trustful cooperation is based on relying on others, while fearful action is based on an apprehension of threat. A "history of play" informs parties on mutual expectations. The irreducibility of shared memories shows that institutional incentives and signals are not able to stabilize shared knowledge on mutual expectations. The paper suggests that different conceptualizations are linked to different modalities of action and that rebuilding damaged relations requires shared reconstruction of a history of mutual relations. The thesis relies on a substantive argument about the particularity of common knowledge and a general argument based on the formal structure of social cooperation.
\end{abstract}

\section{Keywords}

memory; trust; fear; common knowledge; cooperation; Serbia

'I told you the truth,' I say yet again, 'Memory's truth, because memory has its own special kind. It selects, eliminates, alters, exaggerates, minimizes, glorifies, and vilifies also; but in the end it creates its own reality, its heterogeneous but usually coherent version of events; and no sane human being ever trusts someone else's version more than his own.' Rushdie, Midnight Children 
The thesis argued in the paper is that a common knowledge of circumstances of cooperation based on shared memory is the irreducible and necessary ground of social cooperation. An essential part of any pattern of social cooperation is the knowledge we have about each other and about mutual expectations. That it is irreducible means that it cannot be either replaced by any set of institutional incentives or reduced to the social hierarchy of power. ${ }^{1}$ Institutions and power relations are able to structure pattern of cooperation, but they are able to that only so far as they are supporting (or disrupting) confidence in common knowledge on existing motives for cooperation. That a common knowledge on mutual expectation is a necessary condition of cooperation ${ }^{2}$ implies that parties in cooperation need a common ground and that they have to rely on each other, one way or another. Otherwise, the respective mode of action is domination or some other ordered form of action rather than cooperation, and parties are caught in non-cooperative equilibrium based on hierarchical relations and/or mutual fears. ${ }^{3}$

The character of cooperation is dependent on the mutual expectations of parties, expectations that are partially based on a conceptualization of relevant previous experiences. Government and elites cannot put under full control the common knowledge of parties of their respective history. They are not able to invent friends and foes, but they are able to destroy friendships and create foes. The publicly shared stock of common knowledge, which is crucial for creating a sustainable pattern of cooperation, cannot be invented: This possibility supposes a highly implausible "matrix" scenario based on comprehensive and perfect manipulation. The formal

\footnotetext{
1) Martha Minow, for example, has argued the opposite thesis, that "the alternation of forgetting and remembering itself etches the path of power" (Minow 1998: 119).

2) Parties have to trust each other in some degree in order to enter into cooperation. The content of common knowledge is another question. According to Russell Hardin, a minimal condition is that parties have an "encapsulated interest" in cooperation. They know that they have to cooperate more than once and that cooperation is mutually beneficial (Hardin 2002: ch.1). Bernard Williams has argued that recognition of the moral (intrinsic) value of trust in particular groups is essential for cooperation in order to establish a sustainable pattern of long-term activity inside the group (Williams, 2002: ch.5). Presumably, content-free game theoretical explanations presuppose that parties are equally rational and that they have minimal "as if" mutual expectations.

3) John Rawls distinguished three differences between social cooperation and "merely coordinated action." According to Rawls, social cooperation, unlike coordinated action, includes: a) publicly recognized rules and procedures, b) the idea of fair terms of cooperation, and c) the idea of each participant's rational advantage. (Rawls 1996: 16)
} 
and substantive structures of the logic of cooperation are important normative constraints on the side of third parties willing to intervene. On the other hand, common knowledge of mutual expectations is substantive and particular and does not have a unique institutional and social expression. It depends on the content of the history of mutual relations and its interpretation.

Accordingly, any sustainable pattern of social cooperation relies on three overlapping and irreducible backings: an institutionally structured background, the social distribution of power and the distribution of knowledge of mutual expectations. In this paper only the third aspect is discussed. The thesis is elaborated against the particular background of the Serbian experience of dealing with a difficult past. The inability of Serbian society to articulate common experience is an obstacle to collective action and undermines Serbia's trustworthiness and reliability in international cooperation. For this reason, the argument in the paper begins with the identification of some pathologies of public interpretation of the common past of Serbian society. The focus is on divisive aspects of collective memory and their effects on the stability of patterns of cooperation. The argument proceeds with a brief elaboration of the shortcomings of the institutional approach to the problem of trust. The next part consists of the elaboration of different nexuses between memory, trust and fear as modes of actions. The final section explores different modes and effects of political intervention in the content of public memory.

The argument in the paper is normative because it appeals to the good reasons everyone has to accept the intrinsic value of trustful cooperation and to take part in collective efforts at the articulation of the common stock of shared knowledge. For this reason, some valuable contributions, especially on the part of certain radical leftist thinkers, are omitted in the discussion. Their argumentation is far beyond the scope of this paper.

\section{Pathologies of collective memory: Serbian case}

The Serbian political arena is a battlefield of opposing memory judgment. Different layers of the past are a heavy burden for political society in Serbia. Disagreements about the interpretation and meaning of the past are charged with disruptive political potential and open a window to divisive memory battles. The well-known case of Kosovo is probably not only the crucial political issue of the moment, but an interesting case of the 
politically effective presence of the distant past as well. The other hot topics emerging from the recent past are the dissolution of FRY and the subsequent violent wars, war crimes, and NATO military intervention against Serbia. The Srebrenica declaration was only narrowly passed in the Serbian Parliament, with lots of reservations and compromises -including those about the missing word genocide ${ }^{4}$ - whereas the declaration on Serbian victims unanimously passed in the Parliament. The official manhunt for Ratko Mladić, an indicted war criminal, was accompanied with furious activism on the part of right-wing groups propagating Ratko Mladić as a Serbian hero, etc. The political memory work is even more obvious at the lower levels of quasi-political activism. Public life as well as everyday life in Serbia is saturated with unresolved quarrels that emerge from the recent or more distant past (Kuljić 2006).

These are some of the fixed points in Serbian political memory that lack adequate political articulation. A more general problem of Serbian political society is that "missing articulations" are serious obstacles for collective political action. Commenting on Serbian troubles in coming to terms with its own past, former Prime Minister Zoran Đinđić (assassinated in cooperation with members of regular police units and criminal groups on March $12^{\text {th }}, 2003$ ), in the article devoted to the first anniversary of October $5^{\text {th }}$, the day when Milošević's regime was overthrown, noticed that Serbs and their elites are not able to recognize their own greatest historical events as victories (cf. Molnar 2010: 256). This is probably the main reason why Serbia is a state with very few bank holidays, only one of which is a national historical date celebrating a political event. This is the date of the enactment of the first written constitution on February $15^{\text {th }} 1835$, and it is usually poorly celebrated.

What is at stake in these divisive "memory wars" is the memory of real wars waged during the last decade of the $20^{\text {th }}$ century. Serbia was defeated in these wars, but the nature of that defeat is a matter of bitter (and sometimes violent) political contestation. Serbian political society is divided along these lines in at least three opposing political camps, making it impossible to establish rational political communication among them and

4) The Serbian Parliament has passed (March 31 th 2010) the text of a resolution condemning crimes committed in Srebrenica in July 1995. The resolution apologizes to the families of victims and states, "The parliament of Serbia strongly condemns the crime committed against the Bosnian Muslim population of Srebrenica in July 1995, as determined by the International Court of Justice ruling." The resolution was adopted by a majority of 127 of the 173 representatives present in the 250 -seat assembly. 
to bring their positions closer. For the nationalists, it was a military defeat in the unfair battle against the new American imperial project. It was an ideological (for some, identity-based) conflict and Serbia has to endure in her political fight against imperialism. For the moderate, it was the defeat of an unreasonable political project, and Serbia needs a more pragmatic political approach. Liberals believe that it was the defeat of an immoral and shameful nationalistic project and that Serbia needs a new political approach based on a radical reconstruction of political identity. Political parties are divided along these lines.

Serbia is probably a dramatic case in its need to come to terms with its own past, but it is not an exception. Memory studies in the last three decades have demonstrated that a new "guilt of nations" appears with the democratization of history and claims of moral responsibility for the past. Assumed responsibility presents a heavy burden on the legitimacy of the states, especially in international relations (Barkan 2007). The Serbian record in the international political division of moral responsibility is infamous. In addition, Serbia shares the common reputation and record of the Balkan states (Bjelić i Savić 2002). The term balkanization became the B-word, a profane words referring to something dangerous, bad and ugly. The word balkanization is a byword for political dissension and enmity among small and fragmented political units. The Balkans is an area divided into small warring states burdened with eternal instability and turmoil, an area occupied by nations obsessed with history and unresolved conflict coming from the distant past.

Against the background of the Serbian experience it is possible to articulate a normative thesis about the importance of stabilizing the content of public memory in order to stabilize patterns of social cooperation. Shared memory is an important public good because it provides a concrete public conceptualization of the collective social experience as a basis of orientation and action. Divisions and failures in articulation might have serious consequences. According to Bruce James Smith: "Where the images of the past and the affections which attach to these (and around which the action is organized) decay or are pulled apart, where human beings have forgotten or no longer agree on what Walter Lippmann called 'the first and last things,' there is opened up 'a great vacuum in the public mind, yawning to be filled,' and men rush in only to exhaust themselves" (Smith 1985: 4). ${ }^{5}$

5) Bruce Smith recognized three important roles public memory plays in the stabilization of patterns of social and political cooperation. First, continuity between individual and public 
The same word, "yawning gap," is used by James Booth in a different context to refer to the loss of memory, which in turn can undermine the wholeness of society and the continuity of association across time. This hole in memory "can be pathological, a 'gangrene' in their midst" of community (Booth 2006: 179). In other passages of the book, he refers to deep holes in memory as "tectonic plates" of memory, unpredictable in their ability to "undermine reality."

More general reasons for the importance of public memory are grounded in some formal features of social cooperation. Elaborations of the formal structures of cooperation in game theory show that stable and efficient cooperation is a more complex and fragile enterprise than is usually assumed. The modality of cooperation among individuals as well as among groups depends on the common knowledge of expectations of parties entering into cooperation. The substance of this common knowledge is important. If the parties believe that cheating is a dominant pattern of action, they will be trapped in the game of securing assurance against others whom they suspect of desiring to win at the expense of the other. Expectations ascribed to the other party determine rationality of action and the character of the game. It is never rational for one party in cooperation to play according to established rules if she is the only player who plays honestly. In the absence of stabilized patterns of cooperation within a more settled background, every agent or group of agents risks that other parties will not do their part after they have done theirs. Nobody likes to be a "sucker" or "loser" in the cooperative game. If we expect someone or everyone else to cheat, it does not make sense for us to play a fair game, or to play at all. The common knowledge of the character of the game defines the cooperative equilibrium in a particular society. The society of cheaters is trapped in non-cooperative equilibria and required to play corruptive games.

It is an exaggeration to qualify any existing society as a society of cheaters, but most societies are trapped in a stable but inefficient equilibrium.

(collective) memories is essential for building stable and meaningful social and political ties. This thesis relies on Walter Lippmann's work Public Philosophy. Second, political memory is a kind of concrete conceptualization that reduces political action to stories, images, and habits. This conceptualization is able to preserve the virtues and vices of action and to transfer this knowledge to others. This is what he found in the works of Machiavelli, Burke and Tocqueville. Third, the shared stock of memories has to be large enough to create a "fabric of understanding" and provide means for the perpetual reconceptualization of political memory. 
More specifically, this is an equilibrium rising out of the social division of knowledge of the respective past that divides population into mutually distrustful groups.

\section{Two approaches: institutions and shared memory}

The kind of behavior expected on the part of others can be established through institutional assurances of common knowledge of the character of the game and the legitimate expectations of the actors. This is an assumption behind Rawlsian theories of the well-ordered society:

If men's inclination to self-interest makes their vigilance against one another nec-
essary, their public sense of justice makes their secure association together possi-
ble. Among individuals with disparate aims and purposes a shared conception of
justice establishes the bonds of civic friendship; the general desire for justice lim-
its the pursuit of other ends. One may think of a public conception of justice as
constituting the fundamental charter of a well-ordered human association (Rawls
1971: 5).

The assumption is that a particular type of institutional arrangement could provide assurance to all parties sufficient for them to enter into cooperation for mutual benefits and without further fears concerning the motivation of the others.

Taking into consideration Rawls's own reinterpretation of his theory and introduction of two additional assumptions of the reasonableness of the parties and character of public reason introduced in the book Political liberalism, it is safe to conclude that the institutional solution is insufficient. ${ }^{6}$ Two different games may be played according to the same set of institutionalized rules (assuming that a fair play game and a rotten game are different in character). Trust in public institutions is not only the outcome of normatively justified institutional expectations. The interpretation of the history of citizens' real experience in dealing with a particular set of institutions is

\footnotetext{
6) Note Sen's general argument on the limitation of the institutional approach: it is possible in a single society for a perfectly just arrangement of social institutions to exist alongside grave injustices in particular cases (Sen 2009). These difficulties are not necessarily deficiencies in Rawls's theory if it is not interpreted as a general solution of the problem of cooperation but as an articulation of particular experience in dealing with public institutions. Rawls is ambiguous on this question in A Theory ofJustice, but gives preference to the second interpretation in later works.
} 
a good reason for trusting or distrusting the institution. The functioning of political institutions depends on the citizens trusting their leaders as well as believing in the values and ends of institutions, not just on rules, incentives and signals that institutions generate.

Relying on the formal analysis of Amartya Sen $(2002,2009)$ and Bernard Williams $(1988,2002)$, we may conclude that there is no general solution to the problem of cooperation. ${ }^{7}$ Williams says: "The problem of cooperation cannot be solved merely at the level of decision theory, social psychology, or the general theory of social institutions. In fact, there is no one problem of cooperation: the problem is always how a given set of people are to cooperate." (Williams 1988:13) These theoretical findings are supported by many empirical studies (Gambetta 1988, 1993; Rothstein 2005; Tilly 2005).

Thus, it is necessary to look behind institutional incentives. The "history of play" informs parties whether to rely on the others (or institutions) in a cooperative enterprise. The interpretations and knowledge of history are deposited in the shared memory of a particular group. "[P]resent experience was not punctiform, but included a 'comet's tail' of just-past experience, a phenomenon to which he [Husserl] referred as the living present"' (Danziger 2008: 181). Decisions are always made in a context already "saturated by memory." But there is no unique ethical or political expression of shared memories. Memory brings opposite normative possibilities in its wake. It is able to do justice and fuel conflict, provide identity and terrorize. The dark side of memory is usually delegated to the memory of traumatic experiences, but it includes more than this. There are many ills that memory brings with it. One is the ability of memory to "keep alive ancient hatreds" that "have fueled conflicts around the globe." Memory keeps 'wounds green' and the embers of conflict glowing" (Booth 2006: 177). Another is what Dubravka Ugrešic calls the "terror of remembrance" (Ugrešić 1998: 81), which emerges from the "surfeit of memory" (Nietszche, Meier, Blustin). The pressure to keep the common past alive is seen as a burden and obstacle to action.

Different conceptualizations of shared memory give rise to different modalities of action. Thus, in the next part of this article, the nexus between a shared memory and two basic modalities of action - fearful and trustful actions - will be briefly elaborated.

\footnotetext{
7) Sen has concluded that every new situation has capacity building new "mutual conextions" and that boundaries of these connections are going beyond institutionalized structures: "There are few non-neighbors left in the world today" (Sen 2009: 173).
} 


\section{Memory, Trust and Fear}

John Dunn recognized that trust is "both, a human passion and a modality of human action" (Dunn 1988: 73). Along the same lines, it is possible to analyze the relation of trust and fear as two different, sometimes opposite, modalities of action. ${ }^{8}$ Both are concerned with uncertainty over time and coping with the freedom of others as independent agents, ${ }^{9}$ but they bring different expectations concerning the prospects of possible cooperation. Trust is a necessary condition of any cooperative activity, and it includes "the willingness of one party to rely on another to act in certain ways" (Williams 2002: 88). It is not necessary that motives be altruistic or friendly; "the willingness" implies only that cooperative situation is not an occasional but a long-term activity between mutually recognizable parties. According to Williams, "A may have reason to believe that B is a trustworthy person, in the sense that in situations of trust he is generally disposed to do what he is expected to do just because he is expected to do it" (Williams, ibid). "Reasons to believe" are embedded in a particular history of interpersonal relations as well as in social institutions. In this sense, trust is not just a human passion, supposing that we are able to affect our unreflective feeling of confidence in some situations. It is about the relation of trustworthy persons, usually mediated by social rules. A trustworthy person is a credible partner in cooperation for mutual benefit. If we regard trust as a modality of action, the interesting questions are how we can describe a situation of trust given the history of relationships and what we can do (or what policy is appropriate) to build, rebuild or repair social structures of mutual trust among free and independent agents (Dunn 1988: 88).

Fear brings different expectation in cooperative situations. In the situation of fear, parties expect harmful actions on the side of others. It is also assumed that the other party is capable of doing the harm. An apprehension of threat is essential for fearful action. Parties in fearful situations tend to exit the cooperative situation or to assure themselves against harms. The methods of assurance are sometimes extreme, but they are rational from

\footnotetext{
8) Trust and fear as attitudes/disposition admit of degrees. According to values ascribed to them in a particular situation it is possible to analyze an expectations according to ascribed values. Absolute trust and absolute fear are mutually exclusive, but this is probably true for any value above some threshold.

9) The circumstances of trust are described along the lines of German sociologist Niklas Luhmann 1988.
} 
the subjective point of view. Consider an extreme example analyzed by Bo Rothstein:

But if one ethnic group cannot rely on the other ethnic group to accord respect to principles of equal treatment and nondiscrimination, it is pointless for the first group to do so. To cite an extreme (but sadly not at all unusual) case, it may seem rational to try and ethnically cleanse the neighboring village today if you are entirely convinced that the villagers are waiting only for reinforcements in order to attack your own village the next day (Rothstein 2005: 20-21).

Regular cases imply that assurance may have less dramatic, institutional forms. However, complex institutional guaranties against uninvited and feared outcomes increase the costs of cooperation and present an obstacle to efficient collective action. Along these lines it is possible to analyze political development and institutional logic in the case of divided societies. Unfortunately, this is not the exceptional case. ${ }^{10}$ The interesting question here is what is relevant for the process of forming conviction that some individual or group is a clear and present danger.

The answers to the abovementioned questions depend partly on the interpretation of the particular history of the relationships between parties involved in cooperation. Trustfulness or fear are not determined by a decision to trust someone or not to fear someone or something. It is possible to decide to enter into cooperation despite risk and danger, but this is a risky and brave action, not an action based on a trustful and fearless pattern of cooperation. For person A it is possible to rely on the actions of person B only if A believes that they share knowledge of mutual expectations and $\mathrm{A}$ is confident that $\mathrm{B}$ will do his part. Otherwise, someone is pretending that he is in a trust relation with the other. Naturally, one may have false assumptions about mutual expectations or anwrong appreciation of the other's credibility, but this is the case in asymmetrical trust relations, not distrustful relations. Shared knowledge of expectations is not provided only through institutional frameworks. Common knowledge is acquired through a network of social practices that result in a common stock of knowledge. The notion of shared memory is used to refer to an important part of this stock. According to the substance of the stock, self-conceptions and

10) As Michael Ignatieff has put it, "In the twentieth century, the idea of human universality rests less on hope than on fear, less on optimism about the human capacity for good than on dread of human capacity for evil, less on a vision of man as a maker of his history than of man the wolf towards his own kind" (Ignatieff 1997: 18-19). 
conceptions of others are constructed. ${ }^{11}$ Empirical evidence based on neuroscience as well as the social sciences shows that these conceptions are highly stable and difficult to change (Kandel 2006; Rothstein 2005: 21).

There are four features of memory that explains the stability of memory at an individual as well as collective level. The first is that an important part of memory is involuntary. The effacement of memories is not an operative mode of forgetting (Ricoeur 2004: 414). As the psychological literature shows, traumatic experiences are highly stable: The more one tries to forget them, the more vivid they become (Frey 2004). Second, memory is omnipresent in the way that it is impossible to imagine oneself stripped of all memories. Cases of amnesia or partially distorted memory are wellknown examples. Besides that, as has already been mentioned, we are always making decisions "in the horizons saturated by memory." 12 Third, memory tends to create a coherent version of events. Memories are builtin, a kind of cognitive (mental) map, and changes in part of them require changes in other parts. ${ }^{13}$ To change them, it is usually necessary to rearrange the whole construction. Fourth, once established as part of a coherent version of events, memory-based judgments become epistemologically privileged. This suggests that a) other things being the same, someone believes her own version more than someone else's, b) even in the presence

11) According to Jeffrey Blustein, Professor of Bioethics at Albert Einstein College of Medicine, memory is normative and particular at the same time, because it includes a "normative self-conception" based on: a) retrospective reconstruction of the meaning of the past, b) appropriation of the past as my (or our) own past, c) selective thematization of the past episodes; d) interconnections of the previously listed. (Blustein 2008: 66 - 76, 84-86). 12) The same observation (in a different context) can be found in Karl Marx's memorable passage from The Eighteenth Brumaire: "Men make their own history, but they do not make it as they please; they do not make it under self-selected circumstances, but under circumstances existing already, given and transmitted from the past. The tradition of all dead generations weighs like a nightmare on the brains of the living. And just as they seem to be occupied with revolutionizing themselves and things, creating something that did not exist before, precisely in such epochs of revolutionary crisis they anxiously conjure up the spirits of the past to their service, borrowing from them names, battle slogans, and costumes in order to present this new scene in world history in time-honored disguise and borrowed language." < http://www.marxists.org/archive/marx/works/1852/18th-brumaire/cho1.htm> (accessed on December 15, 2011 ).

13) The same is true for trust and distrust. As Daniel Weinstock has put it: "distrust, like trust, is stubbornly evidence-resistant” (Weinstock 1999: 301). Fear is even more stubborn in its persistence against contrary evidence. The widespread fear of snakes is a well-known illustration of this thesis. 
of inconclusive scientific evidence. Memory-based judgments are difficult to change despite their unreliability.

A methodological warning is needed: I am not assuming that memory is an autonomous and self-designative practice, only that it is irreducible. "Remembering ceased to be something that people just do without being conscious of what they are doing" (Danziger 2008: 7). The fact that different concepts, models, practices are introduced and induced changes the nature of memory. Besides the biologically constrained equipment of an individual, "memory concepts, technology, mnemonic values, institutional practices and memory performance [are] linked in a network of reciprocal influence." (Danziger 2008: 9). All of these are included in the creation of a "heterogeneous but usually coherent version of events" - what Rushdie calls "memory truth." However, the veracity of the representation is not the issue here; what is more important is that we use these representations to orient ourselves in physical and conceptual space. We recognize these representations as a part of memory because they are linked to direct past experience, reconstruction of traces of past events or someone's reliable witnessing. For that reason, memory is recognized as fragile and often unreliable, but no less important because of that. This process has its own "logic" that establishes a particular nexus between memorization, remembrance, recollection, and different modalities of actions.

The political elites of the former Yugoslav republic (in all its political forms) underestimated the power of the "autonomous" logic of communicative memory - group memories built on different, formal and informal, social practices. The same is true (the other way around) for official interpretations of the respective history of the states established after breakdown of Yugoslav federal state. The official efforts of political elites to establish a dominant ideological or national pattern of interpretation of the history of mutual relationships collapsed against the background of particular interpretations mediated through long-lasting mnemonic patterns. It does not matter whether the official narrative was about "brotherhood and unity" or "heroic national suffering in a hostile environment." The interesting question is what kind of modalities of actions arose out of the interplay between different conceptualizations of individual and group "real" experiences with institutions and others and shifting institutional settings promoting their own interpretation of mutual history. The thesis, yet to be empirically confirmed, is that interplay between different "autonomous" conceptualizations and shifting institutional settings could explain the extreme commutation of modalities of actions, ranging from brutal 
enmity to civic friendship. Given the multiplicity and complexity of Serbian historical narratives, the other question is what kind of political intervention is appropriate for the stabilization of a common stock of knowledge about the individual and collective past.

\section{Political memory and common knowledge}

The stabilization of the content of memory is not easy to achieve, especially after periods in which "gifted historians" fan the spark of hope for a redemption that is coming from the past. ${ }^{14}$ These are efforts to fill deep holes in memory as "tectonic plates" of memory, unpredictable in their ability to undermine reality. Memory battles over filling this gap, in John Keane words, are "times during which the living do battle for the hearts, minds and souls of the dead" (Keane 1988: 204). These are periods of political crisis and danger. It is not surprising that at the dawn of war in former Yugoslavia this kind of war was waged by writers, historians, linguists, football fans, believers, etc. of different nations and ethnic backgrounds. As an illustration there comes to mind the bizarre memory war waged in the beginning of the Yugoslav crisis, in which skeletons of real and alleged victims of national and ideological massacres during WWII were dug up from mass graves. Skeletons were reburied according to appropriate religious ceremonies without serious identification or forensic analysis. In spite of this, the media were full of horrific pictures and reports of victimization on ethnic and ideological grounds perpetrated in the past by enemies who present actual danger (Ustashi, Communists, Chetniks). ${ }^{15}$

14) Walter Benjamin warned of the role of preachers and prophets in period of danger: "Only that historian will have the gift of fanning the spark of hope in the past who is firmly convinced that even the dead will not be safe from the enemy if he wins. And this enemy has not ceased to be victorious." In every society, especially "in the moment of danger," an "attempt must be made anew to wrest tradition away from a conformism that is about to overpower it." (Benjamin 1968: 255).

15) The heroic effort of a group of historians to clean up the history of the Balkans from hostility and the ghost of violence remains almost unnoticed in Serbia despite a translation and separate Serbian edition (Koulouri 2005). The problem with these materials is that they leave many open and contested questions unaddressed. The strategy of the authors was to pick and choose selected documents in order to achieve overlapping intepretations and to contibute to breaking the memory wars in SEEC's by providing alternative teaching materials. Neither national authorities nor historians recognize the value of this effort. 
Newly promoted public knowledge gave rise to ancient fears and hatred. Nevertheless, fears and hatred were not invented. ${ }^{16}$ They were made present in actual memory through well-known mnemonic practices. Mnemonic practices were used to make it seem credible that Serbs, Croats or Muslims were once again ready to commit genocide against the respective ethnic group. Political intervention in the social milieu of memory has a tendency to abuse memory. Political abuse of memory is a kind of manipulation with the aim of justifying or legitimizing a "system or order or power." It is a corruptive form of political memory, for it tries to establish hegemony of the ruling memory (Ricoeur 2004: 82-83; Northon 1993; Radstone and Hodgkin 2003) ${ }^{17}$ The political abuse of collective memory is not necessarily always counterproductive. ${ }^{18}$ The problem of interventionist abuses is that they are unstable and that these instabilities are able to bring society over to one side of the political axis or the other. Serbia is the actual case in question. Intervention brings different content to the fore and offers an alternative conceptualization. It is an open question whether these interventions are able to induce a change in shared memory and how this is possible. Almost anything may be the object of political misuse, but not everything is changed due to political intervention.

The concept of stabilization refers to the state of equilibrium of different memories that have a capacity for resistance to displacement and a tendency to recover after displacement, either in their original position or in new stable equilibria. The problem of stability is defined in mathematics, physics, economy and biology along these lines. Simply put, political memory is stable if it survives the period of crisis and disturbance. Several types of equilibrium could be described as stable depending on the kind of political regime, ethical burdens and demands, the content of history and the nature of mnemonic practices. What is important is the nexus between individual and group memories on the one hand, and public memory on

16) A good example is the book on political fear written by Corey Robin. Her analysis shows that the political definition of the object of fear is "almost always preyed" either on some real threat or on existing "social, economic and political [threat] that divide[s] a people" (Robin 2004: 16, 18). Fear is always about the appreciation of threat.

17) Paul Ricoeur suggesting that it is possible to apply an idea of justice to the stabilization of content of corrupted public memory. Application of the idea of justice to the memory "comes through our reflection on the abuses of a memory manipulated by ideology" (Ricoeur 2004: 68).

18) Timothy Snyder demonstrates this in the case study of Poland, Lithuania and Ukraine (Snyder 2006). 
the other. The quality of this link depends on certain general features of political memory and the persistence of the irreducible content of memory, which cannot be tamed by public memorization (eg. informal mnemonic practices, traumatic experiences, mass crimes).

For the reconstruction of the logic of stabilization of political memory, three ambivalent characteristics of political memory are important. Political memory a) is a privileged regime of social memory; b) it is interventionist; and c) it pretends to authoritativeness.

a) The privileged status of political memory stems from its relation to political power. It is a memory of power, but at same time constituted and influenced by power. Power brings order to the stock of different political memories. From the period of its formation, the state takes a triple role in the formation of political memory: as producer of history, record keeper and agent of memorization. ${ }^{19}$ In order to achieve this task, authority tends to establish "regimes of temporality" reproduced through mnemonic practices. These are regimes of common remembrance and common forgetting. However, it is impossible to establish supreme control over the interpretation of the past. As Reinhart Koselleck argues in his study of the semantics of temporalization under the effective title Future Past, the present (memory) is always under the influence of the future past - the horizons of past expectation - and there is no power capable of getting rid of them.

b) Political memory is the subject of a deliberative politics of memory aimed at certain important values: peace, reconciliation, justice, democratization. These policies include a variety of legal, administrative and political measures that bring to the public a political imperative of remem-brance. ${ }^{20}$ Their value and effectiveness is widely analyzed in

19) Hegel was among the first to recognize and articulate these intentions on the part of states. In his Lectures on Philosophy of History, G.W.F. Hegel stated that "the uniform course of events [...] is no subject of serious remembrance; though distinct transactions or turns of fortune, may rouse Mnemosyne to form conceptions of them [...]. But it is the State which first presents subject - matter that is not only adapted to the prose of History, but involves the production of such history in the very progress of its own being" (Hegel 2001: 76-77).

20) Melissa Williams (1998) has argued that historical discrimination continues to exist in collective memory and that its working is corruptive of social and political ties. The bonds of trust between majorities and historically discriminated minorities can be repaired by ensuring group representation in institutions, thus ensuring that they have a robust stake in the decision-making process. 
different political contexts, under the flourishing disciplines of the politics of memory and transitional justice. The aim is to intervene in the "spontaneous" or "natural" course of individual and communicative memory in order to correct its fragility, corruption and natural tendency of forgetting unpleasant events. This is a kind of distribution of memory work based on the impossibility of everyone to remember everything all the time. At the same time, it is a corruptive form of memory tending to establish a hegemonic interpretation of the past.

c) Political memory pretends to be an authoritative memory: dutybased memory supported by consideration of legitimacy. What is at stake is political morality, the possibility of mnemonic transformation of a body of formal commands and laws into lasting and binding obligations. Consideration of legitimacy depends on a kind of corresponding memory regime. Truth-based memory regimes prefer discontinuity between individual and group memories on the one hand and public memory on the other. A good illustration of this position is Hannah Arendt's statement: "The best that can be achieved is to know precisely what was, and to endure this knowledge, and then to wait and see what comes of knowing and enduring." (Arendt 1968: 20). On the other hand, identity-based memory regimes would prefer continuity in combination with responsibility. What is important is the protection and preservation of identity-related memories (Margalit, Booth). Democratic regimes prefer recognition through critical contestation (Bell 2008; Markell 2006). The difficult cases are those that include memory of traumatic experiences, mass killings, and massive violations of human rights. No political memory regime is able to stabilize public memory on that basis. These cases have to be addressed on the basis of universalistic moral imperatives rather than on a political memory regime. These considerations go well beyond the present argument. ${ }^{21}$

There are different political ways to bring shared memories home. Some of them are deflective. Deflection arises from different interventions in the

21) The importance of ethical considerations for the stabilization of collective memory in post-mass-crimes periods is minutely elaborated by Nenad Dimitrijević. The thesis advocated in the book is that the Serbian political community has to rebuild its own identity on universal ethical imperatives, because no effort of political stabilization could be morally legitimized. The book goes far beyond the thesis advanced here (Dimitrijević 2011). 
public stock of common knowledge. Different interventions bring different possibilities in their wake. Nevertheless, interventions are an inherent part of mnemonic practices. Mnemonic practices are not innocent and spontaneous. But they have an inherent logic that is difficult to change. As Danziger in his A History of Memory shows, memory is a cluster concept comprising different processes and phenomena. Memorizing information is the process comprising the encoding and storing of information in symbolic forms. Remembrance refers to the process of inscription and retaining information in a material medium. Recollection, recalling, retrospection or reminiscence are different types of retrieval and decoding of information. It is not clear how autonomous this process is and how much it depends on external memory tools and technologies. Some variables include: a) the content of memory is dependent on mnemonic values that are cultural in character; $b$ ) the process can adapt itself to different mnemonic practices and technologies, and c) changing the concepts of memory has an influence on the memory process. Furthermore, the concept has a long history including many shifts in meaning and changes in mnemonic practices. It is difficult to compare mnemonic technique and concepts of memory of ancient bards and storytellers, or a medieval student practicing Ars Memoriae to memorize large portions of Holy Scripture or Latin grammar, with a person who memorize how to use meta-mnemonic tools: pin codes and passwords, organizers and reminders, databases and search engines.

There is a tension between different kinds of interventions and mnemonic practices. Some features of shared memory make common knowledge more stable and less accessible to deliberative interventions. Power and institutions take part in shaping common history and knowledge. Despite this, common history and the stock of knowledge remain contestable and open to interpretation. This is an important substantive constraint. Political attempts toward the collectivization of shared memory and placing it under control are always open to serious suspicion. Stability of conceptualization does not presuppose that it is not liable to change. On the contrary, only the regime of shared memory open to "perpetual public reconceptualization" is capable of stability. In spite of this, there are no guaranties that a common knowledge would become a "fabric of understanding" and mutual trust among citizens more than a fabric of corruption, fears and hatred. The more complex and troublesome the history, the more effort is needed for establishing a sustainable pattern of cooperation. In order to be seen as a trustworthy partner in cooperation, more than 
declared apologies for wrongful past are needed..$^{22}$ To rebuild credibility presupposes that agents link efforts in reconceptualization with modalities of action in other to reconstruct a history of mutual relations.

\section{Conclusion}

The conceptualization of common knowledge and shared experiences is an important public good. A shared stock of knowledge provides the means for public orientation and action. The substance of conceptualization is decisive for the choice of a dominant modality of action among participants in cooperative enterprises. Different conceptualizations give rise to the choice of different strategies. Trustful and fearful actions are taken as examples of actions based on the parties' mutual expectations. The essential part in the constitution of shared expectations is a "history of the game." We make judgments on the integrity or credibility of others, as well as construct our own self-conception, according to previous experiences. These self-conceptions and conceptions of others are highly stable and evidence-resistant. Due to the nature of mnemonic practices and features of memory-based judgments (memory truths) these conceptions are difficult to change. History cannot start again anew every day, as in the movie Groundhog Day. For that reason, deliberate interventions in memory practices are unpredictable in their ability to produce pathological forms of public memory (unhappy memories).

Serbia is a clear case of divisive memories at work. Public life looks like a plateau for different - sometimes pathological and offensive interpretations of the past. Every one of them has a political expression. The problem is that the recent past cannot be framed by old mnemonic patterns. Existing mnemonic practices cherished a Serbian past of heroic

\footnotetext{
22) The seminal form of apology for collective wrongdoing was established by Wily Brant's famous action of kneeling down in front of the monument to victims of the Warsaw GhettoUprising. Political representatives of former Yugoslav states expressed their apology for the collective wrongdoing during wars waged in the 1990 in different forms and occasions. These apologies are often apprehended as empty political gestures without substantive moral meaning for the victims. The loose moral meaning of apologies and the difficulty of decoding the moral meaning of official apologies generally are elaborated in Nick Smith 2008. He states: "I describe how apologies often convey muddled or deceptive sentiments and I prescribe means of decoding such gestures," or "Bad apologies, like spoiled fruit, do not satisfy our primal needs" (Ibid: 10, 1).
} 
freedom fighters, always on the right side in historic battles. There was no place for mass murderers, war criminals, torturers etc. The self-conception of Serbians is still resistant to historical evidence and resilient enough to absorb systematic faults as aberrations and incidents. A hope that institutional incentives for dealing with the past will provide the means for a different conceptualization barely survives. The outcomes of the Tribunal in the Hague (ICTY) or criminal procedures in front of Serbian courts are highly poor in this respect (Petrović 2010). The same is true for Parliamentary declarations, official apologies and new historical textbooks. Rebuilding damaged relations is more complex than giving institutionalized incentives and signals. Otherwise, a new football game or thoughtless statement is able to once again fan a spark of hatred that emerges from the past.

\section{Bibliography}

Arendt, H. 1968. “On Humanity in Dark Times," in H. Arendt Men in Dark Times, (New York: Harcourt Brace \& Company).

Barkan, E. 2007. Krivica nacija: restitucija i ispravljanje istorijskih nepravdi (trans. Lidija Kapičić) (Stylos: Beograd).

Benjamin, W. 1969. "Theses on the Philosophy of History," Illuminations (trans. Harry Zolin) (New York: Schocken Books).

Bell, D. 2008. “Agonistic Democracy and Politics of Memory,” Constellations 15(1).

Bjelić, Dušan I. and Savić, O. 2002. Balkan as Metaphor (Cambridge, Massachusetts: The MIT Press).

Blustein, J. 2008. The Moral Demand of Memory (Cambridge: Cambridge University Press).

Booth, J. W. 2006. Communities of Memory: On Witness, Identity and Justice (Ithaca and London: Cornell University Press).

Brkljačić, M. and Prlendra, S. (prir.). 2006. Kultura pamćenja i historija (Zagreb: Golden marketing - Tehnička knjiga).

Danziger, K. 2008. A History of Memory (Cambridge: Cambridge University Press).

Dimitrijević, N. 2011. Duty to Respond: Mass Crime, Denial and Collective Responsibility (Budapest: CEU Press).

Dunn, J. 1988. “Trust and Political Agency," in D. Gambretta (ed.), Making and breaking cooperative relations (New York: Basil Blackwell): 73-93.

Elster, J. 1983. Sour Grapes: Studies in the Subversion of Rationality (Cambridge: Cambridge University Press).

Gambetta, D. (ed.). 1988. Trust: Making and Breaking Cooperative Relations (New York and Oxford: Basil Blackwell).

—. 1993. The Sicilian Mafia: The Business of Private Protection (Cambridge, MA: Harvard University Press).

Hardin, R. 2002. Trust and Trustworthiness (New York: Russell Sage Foundation). 
Hegel, G. W. F. 2001. The Philosophy of History (translator, J. Sibree) (Ontario: M.A. Batoche Books, Kitchener).

Ignatieff, M. 1988. The Warrior's Honor (New York: HenryHolt and Company Inc).

Kandel, E. R. 2007. In Search of Memory (New York/London: W.W. Norton \& Company).

Keane, J. 1988. "More theses on the philosophy of history," in James Tully (ed.), Meaning and Context: Quentin Skinner and his Critics (Cambridge: Polity Press).

Kosellek, R. 2004. Futures past: on the semantics of historical time (translated and with an introduction by Keith Tribe) (New York: Columbia University Press).

Koulouri, C. (ed.). 2005. Teaching Modern Southeast European History (Thessaloniki, Greece: CDRSEE).

Kuljić, T. 2006. Kultura Sećanja (Beograd: Čigoja štampa).

Luhmann, N. 1988 "Familiarity, Confidence, Trust: Problems and Alternatives," in D. Gambretta (ed.), Making and breaking cooperative relations (New York: Basil Blackwell): 94-105.

Maier, C. S. 1993. "A Surfeit of Memory? Reflections on History, Melancholy and Denial," History \& Memory 5(2): 136-52.

Margalit, A. 2002. The Ethics of Memory (Cambridge MA: Harvard University Press).

Markell, P. 2006, "Recognition and Redistribution," in J. S. Dryzek, B. Honig and A. Phillips (eds.), The Oxford Handbook of Political Theory (Oxford, Oxford University Press: 2008).

Minow, M. 1998. Between Vengeance and Forgiveness: Facing History after Genocide and Mass Violence (Boston: Beacon Press).

Müller, J.-W. 2004. "Introduction: the power of memory, the memory of power and the power over memory," in J.-W. Müller (ed), Memory and Power in Post-War Europe (Cambridge University Press).

Norton, A. 1993. "Ruling Memory," Political Theory 21(3).

Petrović, V. 2010. "Institucionalizacija procesuiranja ratnih zločina u postpetooktobarskoj Srbiji," in Pavlović, D. (ed). Razvoj demokratskih ustanova u Srbiji - deset godina posle (Beograd: Heinrich Böhl Stiftung).

Radstone, S. and Hodgkin, K. (eds). 2003. Regimes of memory (Routledge, London).

Rawls, J. 1971/1999. Theory of Justice (Cambridge, MA: Harvard University Press).

- 1996. Political Liberalism, (New York: Columbia University Press).

Ricoeur, P. 2002. Memory, History and Forgetting (Chicago/London: The University of Chicago Press).

Robin, C. 2004. Fear: A History of a Political Idea (Oxford: Oxford University Press).

Rothstein, B. 2005. Social Traps and the Problem of Trust (Cambridge: Cambridge University Press).

Rushdie, S. 1998. Midnight Children (London: Vintage Books).

Sen, A. 2002. Rationality and Freedom (Cambridge MA: Harvard University Press).

- 2009. The Idea of Justice (Cambridge, MA: Harvard University Press).

Smith, N. 2008. I Was Wrong: The Meanings of Apologies (Cambridge: Cambridge University Press).

Snyder, T. 2004. "Memory of sovereignty and sovereignty over memory: Poland, Lithuania and Ukraine, 1939-1999," in J.-W. Müller (ed), Memory and Power in Post-War Europe (Cambridge: Cambridge University Press).

Smith, B. J. 1985. Politics and Remembrance (Princeton, New Jersey: Princeton University Press). 
Tilly, C. 2005. Trust and Rule (Cambridge: Cambridge University Press).

Ugrešić, D. 1998. The Culture of Lies: Antipolitical Essays (London: Phoenix House).

Weinstock, D. 1999. “Building Trust in Divided Societies," Journal of Political Philosophy 7 (13): 287-308.

Williams, B. 1998. "Formal Structures and Social Reality," in D. Gambretta (ed.), Making and breaking cooperative relations (New York: Basil Blackwell): 3-13.

Williams, B. 2002. Truth and Truthfulness (Princenton: Princeton University Press).

Williams, M. 1998. Voice, Trust and Memory, (Princenton NJ.: Princeton University Press) 